\title{
The dynamics of multicultural Youth Ministry in a changing South Africa
}

\section{Alex Strecker and Marilyn Naidoo ${ }^{1}$}

\begin{abstract}
A missiological mandate to reach out to all people is imperative as more youth ministries become multicultural and there is a need for a safe place to learn and grow spiritually within the local church. This ministry is an important issue that needs to be addressed within a changing society and a changing church culture, as youth ministries are challenged to intentionally and authentically reach out to young people from all backgrounds. Churches that have been traditionally monocultural in their approach need to make adjustments as they work with adolescents representing diversity of all kinds. This article reports on the findings of a qualitative research study carried out in a local church in Pretoria, South Africa providing meaningful insights where there is rather limited literature regarding multicultural youth ministry. The findings underline the need for a broader understanding of multiculturalism that engages in purposeful programming, strengthens genuine friendships, nurtures transforming spirituality and develops leadership abilities amongst culturally diverse young people within local youth ministry.
\end{abstract}

Keywords: Multiculturalism, youth ministry, diversity, South Africa, identity development

\section{Introduction}

With growing cultural plurality and diversity, our society's response to this shift vary from excitement, to watchfulness, and in some cases to rejection, denying the reality that anything has changed at all (Niemand 2012). Nowadays, young people have friends from all around the world and we find youth from other countries "at our doorstep" (Sorber 2010:133) as people continue to "leave their native land because of reasons like oppressive governments, providing their family with the best possible environment, seeking a better life, or because of new job opportunities" (Parks 1999:1). This new multicultural shift has not just changed the world's

1 This article is a summary of a recently completed Masters in Theology (MTh) entitled "A practical theological study of multicultural youth work in Pretoria, South Africa" by Alexander Strecker at the University of South Africa. The co-author Prof Marilyn Naidoo was the supervisor of the research study. Prof Marilyn Naidoo is Professor in the discipline of Practical Theology at the University of South Africa. She can be contacted at naidom2@unisa.ac.za. 
outlook in avenues like business, society and recreation, but in local churches and local youth ministries as well.

Multiculturalism is a growing new phenomenon in churches in South Africa considering its racialised history. According to De Gruchy (2000:40), a new identity quest developed during post-Apartheid within the so-called mainline churches and beyond, as they realised that transformation and reconciliation require fundamental change. Some multicultural examples are Pentecostal congregations such as His People Church in Johannesburg, who have "chosen to be together as a testimony to what God is building in South Africa", and Hatfield Christian Church in Pretoria who value "treating all people as important and unique as they are made in the image of God" (Naidoo 2017:5). Another good example is found within the Methodists, as Bentley (2014:145-156) refers to Glen Methodist Church, who (1) made a bold decision to diversify the clergy to be more representative to the local context; (2) give people freedom, irrespective of their race or gender, to minister within their specific calling and fields of speciality, and (3) ministers are challenged, within their training programme, to serve in racially and culturally diverse contexts, different from their own. The Baptist Union of South Africa is also on a journey from a former monocultural denomination, which accommodated Apartheid, to a multicultural denomination with "more than $50 \%$ of its membership from 'non-white' communities and in its leadership structures", still "the challenges of full integration remain, with a cultural divide always operating below the surface" (Rinquest 2014:97). While denominations endorse the diversity within them, many local churches and youth ministries still struggle to reflect this new-found identity.

Within Christian communities, local youth ministries continue to move toward a more diverse group, "as attitudes are changing on the issue of diversity and multiculturalism" (Parks 1999:1). Amongst others, Christian youth workers have the privilege, challenge and responsibility to lead young people towards multi-cultural competence. Youth leaders are usually older than the adolescents they work with, and may have been raised themselves primarily in a "monocultural" (Bennett 2011:8) society, difficulties and misunderstandings might be inevitable (Lingenfelter \& Mayers 2005:18) as youth leaders aim to nurture a genuine, relevant relationship with the next generation. This article unpacks a research study into how a particular local church understands multiculturalism within its youth ministry, its challenges and opportunities and what can be learnt from this case study concerning multicultural youth ministry generally.

\section{What is Multiculturalism?}

Traditionally the term "multicultural" refers to the cultures of particular racial or ethnic groups, with the emphasis mainly on those considered marginal to the 
non-marginal culture (Wilkerson, 1997:2). The term indicates a pluralistic culture reflected in being "multilingual, multisocial, multiracial and multireligious" (Jenkins \& Kratt 1997:56), as people from various cultural backgrounds share a certain commonness, or even solidary understanding. Multiculturalism can by no means be romanticised or idealised, as several critics of multiculturalism believe that "cultural pluralism will heighten ethnic group identity and lead to separatism, inter-group antagonism, and fragmentation. They consider it to be dangerous to society" (Bennett 2011:15). Some educators in multicultural pedagogy challenge the concept of false self-esteem building which is associated with feel-good lessons that focus on ethnic leaders and contributions, but mask societal inequities (Bennett 2011:34). Vandeyar argues that, "the poverty of this approach is that it does not equip learners, parents or teachers with the tools necessary to combat racism and ethnic discrimination" (2003:195).

Multiculturalism has become an integral part of the scholarly realm in multiple scientific fields. Anthropologist Margaret Gibson (1976) identified five core ideas regarding multicultural education, to set a solid foundation of what it tries to achieve (as cited in Wilkerson 1997):

- Culture and ethnic groups are not equated; instead diversity within an ethnic group is recognised (Wilkerson 1997:16). Uniformity and conformity in all things have been the unquestioned norms of acceptance and belonging; this justified and legitimised segregation in the past (Elizondo 1997:397).

- Education includes out-of-school learning (Wilkerson 1997:16). Multiculturalism needs to be taught holistically, beyond pedagogical institutions, as human beings are born into a particular culture and ethnic community. When students social horizon are expanded, they are exposed to other social institutions, religious communities and political structures (Miller 1997:129).

- Ethnic isolation is antithetical to education, since the development of competencies in a new culture requires intensive interaction with people who are already competent (Wilkerson 1997:16). Ignorance and prejudice will be nurtured through isolation, some may have prejudices about people of other religions, or box them into "nationality" and "race" (Kalungu-Banda 2006:2122).

- Individuals do not need to reject their cultural identity to function in a different cultural milieu (Wilkerson 1997:16). Cultural interchange can become a catalyst in the process of understanding one another; without it individuals might assume that all share the same world view (Sue 2011:3).

- Divisive dichotomies between cultures are avoided, bringing about an increased awareness of multiculturalism as "the normal human experience" (Wilkerson 1997:16). Furthermore, it is important to understand that a per- 
son's motivation is a vital element in multicultural religious education (Ratcliff 1997:99), as individuals are more or less interested and motivated to engage or withdraw in relationships across cultures. Attempting to belong to groups whose standards are in conflict with ours produces emotional stress within us which can lead to "antagonism in our relationship with others" (Lingenfelter \& Mayers 2005:117).

The criticism of multiculturalism has led to the concept "inter-culturalism", drawing on anthropological theories. Lartey (2003:32-33) argues, that intercultural indicates a multi-perspective understanding of diverse persons as shaped by different, interacting cultures and perspectives. Some of the purposes of intercultural education are recognising and accepting the cultural pluralism as a social reality, contributing "to the restoration of a society of rights and of equity" and "the establishment of inter-ethnic harmonious relations" (Laubeova Alvarez \& Lorenzo 2003:7). These purposes actually coincide with the foundational principles and conceptual framework of multicultural education which are cultural pluralism, antiracism, the elimination of structural inequities, the importance of all cultures in a diverse society and equity in education (Bennett 2011:4). Power issues still remain a constant challenge, as multiculturalism might be used in order to control or manage diversity, as some progressive political analysts perceive it as a tool to sustain dominant interests under the guise of extending political and cultural suffrage to minority groups, this critique needs be taken seriously, exposed and acted against (Gunew 2004:40). Inappropriate assimilation, which might be the case in specific settings, should not be desired. Fortunately, equity pedagogy suggests an ongoing quest for equality for all learners in the educational realm (Bennett 2011:5). This is especially the case in multicultural congregations which strive towards cultivating mutual trust in a process of reciprocal exchange within a culturally diverse community (Parker \& Girgis 2005:66-67).

One has to acknowledge that while acts of racism are being called out in South African society there is still work to be done as white people have been taught not to see one of its corollary aspects namely, "white privilege" (McIntosh 1990:1), which puts some at an advantage. This is also found in the ecclesial realm, as churches have become "arenas for subtle racial tension" of homophobia and sexism, instead of being "places of acceptance and love" (Naidoo \& De Beer 2016:3). The difficulty is that, "race is seen as an objective entity" by many, rather than as "socially constructed" (Naidoo 2017:2). "This inadvertently silences the reality of race, and suppresses the idea that if these concepts are socially formed, they can equally be changed socially" (Naidoo 2017:2). Therefore, unpacking issues of power and structural inequalities would make for interesting future research. In this study, as a launching pad into social relations within South Africa, the concept of multicul- 
turalism is significant as it focuses on the appreciation of culture which needs to be tested within youth ministry, as cultural differences are commonly accepted, and prejudices reduced amongst the younger generation.

\section{Multiculturalism and Youth Ministr}

Different scholars provide several well-thought through and tested youth ministry approaches. Senter, Black, Clark and Nel (2001) engaged in a constructive dialogue in their co-authored book "Four Different Views of Youth Ministry and the Church". Nel in his "inclusive congregational approach" (2001:3) argues that young people should be included in the eight-fold ministry of the church, while Black considers a "preparatory approach" (2001:40) which can be defined as a specialised ministry to young people that prepares them to participate in the life of existing churches as leaders. Clark indicates with his "missional approach" (2001:87) that adolescents and their culture need to be taken seriously enough to provide them a sociological and theological bridge from the secularised world of the youth into a broad and loving community of faith. Senter joins in the conversation with the "strategic approach" (2001:117), which creates a community of leaders and youthful Christians that enables a para-church or church-based youth ministry to establish a new church, expressing faith in a community relevant to both Christ and culture. Furthermore, Fields' youth ministry approach places an emphasis on "purpose" (1998:47-50) as he argues for several components in youth ministry that carry the intrinsic value of evangelism, worship, fellowship, discipleship and ministry before implementation. This is in opposition to creating a purpose for activities after the fact (Jones 2001:153) and is in accordance with Boshers' four-point strategy to re-evaluate (1997:17), minister (1997:67), structure (1997:137) and program (1997:211) with purpose. Both attempt to challenge youth leaders who just load their calendars with events and then seemingly try to justify their presence by giving a spiritual purpose to each. Clark more recently developed an "adoptive" (2015:82) understanding concerning youth ministry, critiqueing the segmentation or even abandonment of young people, as "midadolescents have been forced to design their own world and separate social system" (2011:27), instead of "offering them a mutual, empowering, engaging, and supportive new family" (2015:85).

Even though all of the abovementioned approaches vividly explain and discuss important issues crucial to relevant youth ministry, no explicit focus is given on the cultural diversity within todays younger generation. But, if no attention is given to multiculturalism, teenagers "will read between the lines and pick-up the message that Christ unites only those of similar backgrounds" (Sorber 2010:131), as traditional youth ministry approaches have limited impact in the lives of Christian adolescents due to the lack of importance placed on the socio-context within the 
daily lives of the younger genaration. Young people will be disconnected from the youth ministry of the local church if it does not match the rest of their culturally diverse world (Sorber 2010:131). This coincides with Roebben's view, that churches should not leave young people behind as "they are searching for good reasons to ground their hope for a better world, and therefore they are desperately looking for 'soul food"' (2009:4). Sorber purposefully promotes multicultural youth ministry around one foundational principle, called "diversity" (2010:133), as "today's youth ministries need to be diverse to connect to the diverse youth culture that is fast becoming the norm" (2010:143). Embracing differences of ethnic groups, cultures and individuals is the focal point of this approach. Furthermore, as all cultures are of equal importance and even complement one another, multiculturalism within a purposeful setting like, a culturally diverse youth ministry, will support the missioligical call to reach all nations with the love of Christ as adolescents can become "Christians with a world vision" (Parrett 1999:43).

It is also important to note that adolescent development is a challenging developmental stage, as it can cause uneasiness or discomfort in disclosing personal opinions for young participants (Norris, Aroian, Warren \& Wirth 2012). Wellknown psychoanalyst, Erik Erikson (1968) proposes eight stages in psychosocial development (Schellebach 2007). Each stage is characterised by a "crisis" caused at that point in development because of the interplay between the internal forces of biology and the specific demands of society (Steinberg \& Morris 2001:91), for example puberty is known as a time marked by experimentation filled with emotional storms and stress (Heath 2007). The challenge of adolescence is to resolve the identity crisis successfully, to emerge from this period with a meaningful selfunderstanding and a clear view for further development.

\section{The Research Project}

Qualitative research was conducted for this study as it is an appropriate way to explore the social world in an attempt to access and understand the unique ways of individuals and communities within it (Swinton \& Mowat 2006:29). The case study approach provides the framework to gain a deeper holistic view of the research problem, and facilitates different stances, describing, understanding and explaining the research problem (Baškarada 2013:1). The focus of the research was on a single case (Creswell 2007:74) about the youth ministry of Eastside Community Church. The main research question was whether the current practices of youth ministry at Eastside Community Church are part of a multicultural approach that enables relevant youth ministry. Relevance, in terms of this study, focuses on embracing differences between ethnic groups, cultures and individuals, where diversity is celebrated. 
A descriptive-interpretive framework of Osmer (2008) was used to conduct an analysis of the case study. According to Smith, Osmer's four core tasks are identified in an attempt to equip congregational leaders to engage in the practical theological interpretation of situations in ministry, as well as theological educators to train students in the skill of practical theological reflection (2010:99). The four tasks include, (1) the descriptive-empirical task which asks the question, "What is going on?", (2) the interpretive task focusing on the question, "Why is this going on?", (3) the normative task which asks the question, "What ought to be going on?", and (4) the pragmatic task which asks, "How might we respond?" (Osmer 2008:4; Smith 2010:99-100). This research uses the two former tasks, but these should not be viewed in isolation as all four tasks are inter-dependent at their core and they should be seen as a whole (Osmer 2008:220).

Eastside Community Church in Pretoria was the purposefully-selected sample because of its culturally diverse congregation whereas other churches in the area are mainly monocultural. It is affiliated with the Baptist Union and concurs with its general Baptist principles (Scheepers 2012). With their main campus situated in Moreleta Park, Pretoria (Moreleta Eastside Community Church 2016), the majority of people from Eastside Community Church come from middle- to upper-class social backgrounds in the suburb. A few families who also attend the church are from an informal settlement called "Plastic View", which has emerged in the past ten years close to the church property. This church stands out in this regard, as they engage with culturally and socially different groups, in a community which is historically white-suburban. Even though the leadership of the congregation was not intentional about being multicultural, it has become exactly that - more multicultural and multiethnic (Niemand 2012). In addition, an ongoing influx of families from Nigeria, England, Germany, Argentina, Egypt, the United States, and many more countries have become an integral part of the congregation for nearly two decades. The culturally diverse face of Eastside Community Church is, to a certain extent, reflected in each ministry department, including the youth ministry. Their youth group was selected because of its unique multicultural dynamic as several different cultural and ethnic groups were present.

Data was collected from all six youth leaders (all white participants with an equal number of female and male youth leaders) through in-depth interviews in order to receive a comprehensive understanding of the issue. Carefully drafted openended questions were used, namely: "Can you explain what the term 'youth ministry' means to you? Can you describe the term 'multicultural'? Can you say more about some experiences you had concerning multicultural youth ministry? Can you describe the multicultural youth ministry in your church?" The data was collected in 2013. Furthermore two focus groups consisting of youth from the congregation, 
were conducted instead of individual interviews. The youth had known each other for several years and this provided a comfortable environment for them to share their experiences. The focus groups consisted of adolescents from 14-17 years old, from diverse cultural backgrounds. Adolescents were purposefully allocated in same-gender groups to prevent uncomfortable situations between the sexes that might have hindered individuals from freely expressing their opinions.

The data analysis focused on what Stake defined as "direct interpretation" (Creswell 2007:163; Stake 1995:74), refering to the researchers' impressions as the main source of data and making sense of these impressions as the analysis, precedence is given to intuition and impression rather than guidance of the protocol, although it is recognised as significant (Yazan 2015:145). Specific actions were arranged, and properties categorised (Stake 1995:74) in this process and the data was pulled apart and put back together in a more meaningful way (Klenke 2008:67).

\section{Theoretical Framework}

In this study, the word "multiculturalism" refers to all races, ethnic groups and cultures, as mentioned earlier. For this study Parrett's missional-based multicultural youth ministry approach (1999:38-45) was used which entailed ten specific commitments for youth leaders as they work with adolescents from diverse cultural backgrounds:

1. Focus on the greatest commandments to love God, yourself and others; including a willingness to love across cultures.

2. Focus on the great commission, which emphasises a commitment to be concerned for all people in the whole world.

3. An emphasis on reconciliation; as God reconciled himself through Christ to the world, people should engage in the ministry of reconciliation.

4. A strong commitment to honesty and faithfulness in interpretation, application and teaching of the Bible as everyone reads the Bible through a specific cultural lens.

5. A healthy cultural self-knowledge, to understand how their own cultural and ethnic background has shaped an understanding of life, faith and God.

6. An understanding of the ethnic and cultural influences which affect and effect young people.

7. A commitment to love and respect each young person as an individual without general preconcieved cultural assumptions.

8. A willingness to build relationships with people from other cultures.

9. A commitment to be stretched beyond the personal comfort zone; as ministering amongst a diverse young generation can be overwhelming, endurance and advanced cultural education are of vital importance. 
10. A commitment to revisit all of the commitments at regular intervals.

As it is pivotal that the ministry to culturally diverse adolescents reflect the dynamics of their generation in order to develop a genuine foundation youth leader's can build on, Parrett's (1999:38-45) biblical-based approach concerning multicultural youth ministry was chosen as the framework for this study. This is because his approach with its ten commitments concerning multicultural ministry provides a theologically sophisticated framework with the support of Sorber $(2010 ; 2016)$ and Parks concerning a culturally diverse youth ministry. While several helpful youth ministry resources like, Student Ministry for the 21st Century (Boshers 1997), Purpose Driven Youth Ministry (Fields 1998), or Family-Based Youth Ministry (DeVries 2004) explain important challenges concerning young people, they do not intentionally focus on the dynamics of multiculturalism.

Parrett's framework guided the interview questions above, focusing on Parrett's ten commitments, as they teach youth leaders how ministry amongst diverse teenagers can be theoretically and practically implemented in a significant way. Moreover, the first and second commitments embrace the missional understanding of the great commandment and the great commission, as both equally call to embrace otherness and reach people of all kinds. Furthermore, South African youth ministry resources such as "Future Church Now" (Codrington 2010), Nel's "Inclusive Congregational Approach" in Four Views of Youth Ministry and the Church (2001) or "Youth, Faith \& Culture" (Maiko 2007) seemingly focus on either a more Western or more traditional African approach, as they do not present an explicit post-modern multicultural approach to youth ministry.

\section{Findings}

Within the research process the data was reconceptualised into different significant themes. The themes emerged by systematically working through the data, focusing on the content and assigning open codes, and grouping similar data into categories. Moving from open and colour coding to axial coding, categories were grouped into the emerging themes of: multicultural understanding, purposeful program, relationship-centeredness, transforming spirituality, and leadership ability. Furthermore, three of the themes were identified as areas of growth, while the other two areas were identified as areas of strengh within the local youth ministry. These will be unpacked in this section.

6.1 Areas of growth within the church regarding a multicultural youth ministry 6.1.1 The need for a comphrensive understanding of multiculturalism

Several youth leaders explained the importance of cultural engagement, like not discriminating against others, being globally aware and being willing to change 
mind-sets, to strive for genuine equality and cross-cultural learning. One youth leader described multicultural understanding through a talent evening with the adolescents as, "it's the coming together of all the different cultures and being able to respect the other culture and be able to live with each other without stepping on toes or being hurtful or without realising that is not a cultural practice". For leaders to mention examples like the above was encouraging as it broadened the personal understanding of each individual involved. However, multicultural understanding seemed to take a simple, naïve reality in the minds of the the youth leaders, especially some of the younger leaders who subconsciously stepped in the "colour-blind" trap (Sorber 2010:38). The misinterpretation of the term "I'm colour-blind" can create a concern, as this attitude can underline an unwillingness to truly understand the distinctiveness about another person's ethnicity and culture (Parrett 1999:35). The more mature youth leaders, who grew up in a monocultural environment and experienced Apartheid first hand, seemed to be more able to recognise and differentiate multicultural issues than the young adults. Therefore, they dealt better with current cultural differences, like recognising cultural misunderstandings and appreciating different cultural traditions. This was evident in the older youth leaders critical responses as they reflected, "for us it's quite a big mind-set change to start integrating the cultures" and "there's a difficulty for the kids from different cultural backgrounds to integrate and to sort of interface with each other".

As diversity has its natural and societal limitations, as well as prejudicial exclusion, purposeful nurturing relationship development through understanding people from different cultural and social backgrounds is pivotal (Parrett 1999:43). The key to multicultural understanding is to break with monocultural standards and to promote cultural pluralism, antiracism, cultural teaching, and the need for equity (Parker \& Girgis 2005:28) in the sphere of youth ministry and the local church. Issues like these were unfortunately seldom the focus of the conversations with the youth leaders and therefore were not idendified in the responses of the adolescents. Multicultural understanding is formed through a rigorous implementation of four pedagogical dimensions, namely equity pedagogy, curriculum reform, multicultural competence, and social justice concerning multicultural education (Bennett 2011:5-8), which equips and forms the adolesents' minds and behaviours concerning other cultures, this definitely needs to be further taught and implemented within this cultural diverse youth ministry.

\subsubsection{The need for more purposeful programmes}

The importance of well-organised and planned special events and regular meetings surfaced in the analysis. Structure, which is needed within a regular programme, 
provides sustainability in youth ministry. A youth leader explained that a regular Sunday morning meeting was divided into three different sections, for instance, "there would be a game in the beginning or some kind of 'ice-breaker', then there would be a Bible study and try to make it as interesting as possible by doing a drama and there would be a 'God Slot' which is sort of like a fun way of explaining the lesson of the day" to reach the different adolescents through varoius creative education styles. Some adolescents, in this regard, showed critical awareness and concern regarding the youth programme, as suggestions, like to "make that game much more involving with other people so that you can build relationships during a game" were made.

Concerning multiculturalism, a youth leader observed the effectiveness of a purposeful, creative programme as, "wherever there were group activities and games they blended in together, when we have games and activities, then it kind of diminishes (cultural barriers), falls away." This was not enough for some oft the adolescents as they urged for a cultural open day with people "from other schools and then to come together whenever you can and learn about culture and then mix it all" (different foods, different music, different dancing). The danger in this apporach is not to become programme and entertainment driven, at the cost of nurturing deep engagement between diverse adolescents.

Intentionality is crucial for purposeful engagement with and understanding of other cultures, as all perspectives from all people involved are of equal importance. A ministry that wants every culture to feel at home, takes intentionality seriously, yet people struggle to apply the principle of intentionality to cultural diversity (Sorber 2016). If intentionality is well-implemented it will create influence. Ratcliff (1997:116) mentions three methods of influence in multicultural religious education, (1) compliance, which implies to understand and appreciate a different culture which can result in interaction; (2) identification, this occurs when a culture appears attractive, which creates further interest in the topic and (3) internalisation, as individuals adopt another's perspective as their own, rather than simply responding to examples. These methods of influence can be purposefully implemented in a regular yet diverse youth ministry programme. While the first two of these methods are part of this local youth ministry further actions need to be taken to truly internalise cultural diversity amongst all people involved in it.

A concern which was highlighted by some of the youth leaders was the side-lining and marginalising of the adolescents within the wider congregation in general, as young people have only partially been given the opportunity to be "involved in the service". The reason behind the marginalisation of the younger generation might be the struggle of a "mismatch" as a sign of "the growing cultural gap between world 
and church" (Savage \& Collins-Mayo 2011:156), but also amongst the generations within a local church. If the entire church cannot become a role model in purposefully developing and implementing a culturally diverse programme that recognises and stengthens all cultures the youth ministy with its distinctive otherness will eventually become alienated. A good example was the desire of some adolescents who mentioned the lack of programmes within the youth ministry focusing on social and community involvement. Critical statements like, "we used to go to like orphanages, the Teen-Church never does that type of thing", and "there could be a little bit more involvement in ministry when it comes to the youth", showed the desire and need for community programmes, where culturally diverse adolescents can be practically and purposefully involved, as a common purpose strengthens unity with a diverse group.

\subsubsection{The need for more multicultural leadership ability}

Most youth leaders involved in the study were themselves previously part of a youth ministry in their adolescence, because of their personal experience with Christianity and as they had clear role-models they followed in their footsteps. For example, a youth leader openly shared in the interview, "I got a lot of struggles at that age of my life and the youth ministry was there for me and they supported me, and they grew me." This vital reality was strengthened by some of the adolescents comments like, "and then I wanted to be a leader at holiday club for the longest time". This showed a clear desire for empowerment and leadership development which was partialy exemplified by the leaders. Within this diverse youth ministry the difficulty was, while adequate, shared leadership is important for any ministry, timing, human recources, proper development and wise implementation are hard to figure out. As some youth leader's critiqued that "we kind of have to take who we get, because we are always short of hands". If the youth ministry is understaffed or ill-equipped, leaders will be unable to develop the ministry and nurture young leaders, as their levels of expertise and training are unfortunately lacking (Codrington 2010). In my opinion it is impotant to be inclusive in this regard, indicating the importance of diverse experiences, attitudes and perspectives that are shared during a multicultural exchange. This is needed in leading and equipping young people, as well as developing culturally diverse leadership skills.

Some aspects that were mentioned by the youth leaders, concerning youth leader abilities, were the need for a holistic view, the need for diverse personalities and serving attitude, visionary leadership and to care for diverse adolescents. As these realities cannot be fullfilled by an individual alone, a dedicated, gifted, wellequipped and mixed team is indispensable (Boshers 1997:151; Fields 1998:271). Concerning the team diversity some youth leaders suggested that "it would be nice 
if we could have teachers who could interact with the other cultures better" and critiqued that the current team is "non-multicultural". The answer on how to develop a culturally diverse ledership team lies within the adolescents' desire from this local youth ministry. They do not just want to be ministered to, but desire to be empowered to minister to each other and to others. Therefore, the youth leaders need to understand that their adolescents are, "the best opportunity to launch a vital Christian witness to shape the faith Community for the next generation" (Senter, Black, Clark \& Nel 2001:117). I am convinced that, as the younger generation operates within a culturally diverse setting, these adolescents are a good nurturing ground to develop more multicultural leaders within the youth ministry.

\subsection{Areas of existing strength within the church concerning multicultural youth ministy}

\subsubsection{Healthy social relationships within the Church}

A strong focus was shown by the youth leaders towards a genuinely inclusive, open, and welcoming approach regarding friendships towards diverse adolescents. Suggestions from youth leaders to establish a "one-on-one basis with a teenager, to really walk a road with them, being involved in their lives" showed a genuine interest and desire to deeply connect with a diverse young generation. Comments from some adolescents supported this understanding as well when they state, "a place where you know a lot and you know you won't be judged on what you wear and talk". To develop this genuine safe place is only possible as diversity among young people is accepted, nurtured and enjoyed. Focusing on individual interactions rather than result orientation by keeping in mind the struggles, misunderstandings and challenges which young people face is important. This indicates the need for authentic relationships, as young people expressed a desire to be real, accepted, loved and respected as individuals. Furthermore, within the study some youth leaders shared experiences that integrated different learning styles and used creative methods to holistically educate culturally diverse adolescents through different interactive and multifaceted activities. A youth leader shared, "if you teach them a Bible story and ask them to read the Bible at the following questions or whatever you kinda lose them. Where if you do a play, a skit or, a game, then you get their attention again", which clearly showed the use of the different learning styles to reach, teach and properly engage with diverse adolescents. To purposefully use the different cognitive learning styles, which can been linked to cultural differences (Pithers 2002:119) is a significant factor in avoiding unncecessary cultural misunderstanding and in communicating with culturally diverse adolescents, in order to know these differences, genuine relationships need to be in place. According to Bennett (2011:215) field-sensitive learners tend to draw upon those around them 
for guidance, for information in unfamiliar or ambiguous situations, and field-independent learners tend to be more analytical than field-sensitive learners. Several youth leaders showed a willingness to get to know the adolescents with all their differences in order to reach, teach and care for them.

The youth leaders understood that growing friendships amongst and with adolescents is necessary for personal and community growth within the youth ministry. One youth leader mentioned an experience, "when I opened up to them it was subject opening and they just opened up, it was a really deep and intense conversation, and you could really connect to them". Furthermore, young people enjoyed the genuine, deep friendships that developed with the youth leaders and other Christian peers since many faced a hostile environment within their everyday lives. This showed an open and vulnerable attitude towards culturally diverse young people which is vital to nurture genuine friendships. More so, is it undeniably crucial to show culturally diverse adolescents genuine care, therefore the youth leaders need to be humble towards them and their situations (Sorber 2010:137), which was strongly evident in this study. Unfortunately, a few youth leaders permanetly struggled to relate to culturally diverse adolescents. One youth leader mentioned that, "it's difficult to participate in their lives in a deeper, meaningful way, because to do that you have got to build trust and building trust is a two-way thing", as the adolescents "must trust you and be able to open their hearts and disclose things to you". Therefore, it is important for the youth leader to be willing and interested not only to minister to the adolescent, but to be informed and know about their culture, interests and personal life story (Parrett 1997:42), and to intensionalise familial relationships within appropriate boundaries (Clark 2015:89). While most youth leaders were able to develop strong trust relationship with the diverse young generation of the local church, a few felt that they were falling short in this regard.

\subsubsection{Strong Christian spirituality}

Most youth leaders described transformational realities like fellowship, evangelism, prayer, unity in diversity, worship, personal reflection, critiquing personal faith, different Bible interpretations, growth and maturity as very important factors in a diverse cultural youth ministry. Comments like, "I think engaging is on the one hand about, I guess let's say on a Sunday ministering to the group about Christ and the Kingdom, but it needs to be more than that", and to "not just necessarily preaching God to them, but showing them God through acts of love and kindness" suggested a more meaningful ongoing spirital formation process, rather than an once-off spiritual persuasion. According to McLaren (2006:181), youth leaders need to magnify the importance of faith and its dimensions as scientific certainty breaks down from theory to real-life; ultimate certainty is surely available to God, but part of our hu- 
man predicament is the gap between our aspirations for absolute knowledge and our ability to attain it. A genuine spiritual desire was mentioned by several adolescents as, "it's like opening our mind on what our future like, Christianity and so on" and "the friends I have here, it's even more like in depth, kind of welcoming, you're allowed to talk about your faith, like it's not weird cause it's cool".

Concerning the spiritual reality within musical worship a youth leader explained the difficulty of cultural styles they tackle as somebody asked, "can't we make the music more, the worship more appropriate for all cultures?" This was confirmed by some adolesents as they critiqued linguistical, and theological stances in worship music because, "if we don't understand some of the words that we're singing in some songs, explain what it means, so that we can know what we sing before we're actually singing" as well as the duration, "we can make the worship longer and some more songs at Youth". Elizondo (1997:404) encourages, multicultural religious education within Christian ministry towards culturally diverse young people, to approach issues with prayerful insight, with patience and trust, and to pursue a welcoming and inclusive home for all. The willingness to acknowledge this desire and the willingness to mix musical worship styles as requested shows a positive and unifing spiritual approach in this local youth ministry.

The challenge of traditional religious practice within the multicultural realm, which puts young people under pressure to conform concerning their faith, was recognised by the youth leaders, as some parents came from different African tribes, Afrikaaner tradition or European background. A youth leader explained that adolescents start asking critical questions like, "'Okay, is this God my God, or is this my parents' God?' and I think a big thing for the young guys is to choose Jesus for their own." The power of culture must be recognised as all people are shaped by the force of culture, and cultural views are meaningful and powerful for members of some cultures (Parker \& Girgis 2005:27). The youth leaders managed to look at the unifing characteristics of the Christian faith and learned to accept and deal with cultural differences and challenges in this regard.

\section{Implications}

This study has shown that the youth ministry of Eastside Community Church is multicultural to some extent, as culturally diverse young people regularly participate and identify themselves with this local ministry. To sustain, strenghten and further develop a multicultural youth ministry certain recommendations were suggested. Firstly, culturally diverse leadership development which includes identifying and incorporating new diverse youth leaders and the development process of a "leadership pipeline" (Charan, Drotter \& Noel 2001; Metanoia 2017) for diverse adolescents within the ministry. This might be challenging and time consuming, or even frustrat- 
ing at times as culturally sensitive youth leaders continue to be scarce, but investing in potential young culturally diverse leaders now will benefit youth ministries in the near future. Secondly, a purposefully drafted culturally diverse programme (Sorber 2016) consisting of relational community involvement (Codrington 2010) and creative multicultural religious education (Wilkerson 1997), will give proper structure, common identity and clear guidance to a multilingual, multiethnic, multisocial group of culturally diverse adolescents.

This case study may be limited and cannot be generalised, however, it highlights issues that other churches may encounter in youth ministry and need focused intervention to meet the needs of social integration in a changing society. Motivational factors that impact churches generally to move towards multiculturalism range between an opportunistic approach, as people from diverse backgrounds join local churches, and environmental changes, like migration and globalisation, to a concious missional calling (to reach people from all nations) in South Africa. The evangelical tradition, which this local church is part of, tends to sideline socio-political realities which have to be faced in a culturally and socially diverse community, as the missional focus of going out and embracing the other, needs a holistic multicultural understanding and practical approach. Issues that are necessary to authenticate ministry are to communicate a constant awareness concerning the inequalities in a multicultural society, to continously encourage and embrace identity regarding unity in diversity, and to pursue an ongoing practical development process towards a multicultural youth ministry.The limitation of the research was that there was an inadequate social and ethnic mixture of youth leaders in this sample, as this study was located in a specific time and social context, namely a suburban middle-class area. Further research should engage in other socio-economic settings and in other denominational traditions in South Africa.

\section{Conclusion}

The multicultural journey in general is still emerging in this church and will expand and grow as more people and ministries engage in the journey (Parker \& Girgis 2005:71). When confronted with difference, otherness, the unfamiliar or foreign, it often seems logical, after some initial excitement, to retreat, be suspicious or even discriminate and exclude instead of being brave and embracing the other person or people group. The participants of this research are permanently confronted with uncomfortable and difficult situations. From their childhood on they are challenged to grapple with how to understand and respond to a culturally diverse society, how this affects them and how it is reflected by the local church ministry they are an integral part of. They still need to walk a long road to fight discrimination and racism, teach equality and further embrace, nurture and celebrate diversity. This article 
highlights the need for more scholarship on multicultural youth ministries, efforts to enable a genuine mixing of racial and cultural groups in churches, to rethink traditional monocultural youth ministry approches and to move towards ministering purposefully to a culturally diverse younger generation.

\section{Bibliography}

Baškarada, S. 2013. Qualitative Case Study Guidelines. Victoria: DSTO.

Bennett, C.I. 2011. Comprehensive Multicultural Education. Theory and Practice. 7th Edition. Boston:

Pearson Education.

Bentley, W. 2014. "Ministry as Bridge Building: Facilitating Culturally Diverse Faith Communities in

South Africa" in Smith, R.D., Ackah, W. \& Reddie, G. (eds). Churches, Blackness, and Contested Multiculturalism: Europe, Africa and North America. New York: Palgrave Macmillan, pp.145-156.

Boshers, B. 1997. Student Ministry for the 21st Century. Grand Rapids: Zondervan.

Charan, R., Drotter, S. \& Noel J. 2001. "Six Leadership Passages" in The Leadership Pipeline. San

FranciscoL Jossey-Bass, pp. 15-32.

Clark, C. 2011. "Abandonment - The Defining Issue for Contemporary Adolescents" in burt 2.0 - inside the world of today's TEENAGERS. Grand Rapids: Baker, pp. 23-42.

Clark, C. 2015. "View Three - The Adoption View of Youth Ministry" in Clark, C. (ed.) Youth Ministry in

the 21st Century - 5 Views. Grand Rapids: Baker, pp. 72-90.

Codrington, G. 2010. Challenges Facing Youth Ministry in the 21st Century. Accessed from $<$ URL $>$

http://www.futurechurchnow.com/2010/07/28/challenges-facing-youth-ministry-in-the21st-century/ [Accessed on 25th June 2016].

Creswell, J.W. 2007. Qualitative Inquiry \& Research Design: Choosing among Five Approaches.

California: SAGE Publications.

De Gruchy, J.W. 2000. "The Chastening of the English-Speaking Churches in South Africa" in Van Vugt,

W.E. \& Cloete, G.D. (eds). Race and Reconciliation in South Africa: A Multicultural Dialogue in

Comparative Perspective. London: Lexington, pp. 37-52.

DeVries, M. 2004. Family-Based Youth Ministry. 2nd Edition. Downers Grove: IVP.

Elizondo, V. 1997. "Benevolent Tolerance or Humble Reverence? A Vision for Multicultural Religious

Education" in Wilkerson, B. (ed.). Multicultural Religious Education. Birmingham: Religious Education Press, pp. 395-406.

Fields, D. 1998. Purpose Driven Youth Ministry. Grand Rapids: Zondervan. 
Heath, S. 2007. Youth/Adolescence. The Blackwell Encyclopedia of Sociology. Accessed from <URL> http://0-www.sociologyencyclopedia.com.oasis.unisa.ac.za/subscriber/ tocnode.html?id=g978109781405124331_yr2016_chunk_g978140512433131_ss12 [Accessed on 22th June 2017].

Gunew, S. 2004. "Colonial Hauntings: the colonial seeds of multiculturalism" in Haunted Nations: The Colonial Dimensions of Multiculturalisms. New York: Routledge, pp. 33-50.

Jenkins, C.A. \& Kratt D. 1997. "Sociological Foundations of Multicultural Religious Education" in

Wilkerson, B. (ed.). Multicultural Religious Education. Birmingham: Religious Education Press, pp. 56-92.

Jones, T 2001. Post Modern Youth Ministry. Grand Rapids: Zondervan.

Kalungu-Banda, M. 2006. Leading like Madiba: Leadership Lessons from Nelson. Cape Town: Double Storey Books.

Klenke, K. 2008. Qualitative Research in the Study of Leadership. Bingley: Emerald Group Publishing Limited.

Lartey, E. 2003. Living Colour: An Intercultural Approach to Pastoral Care and Counselling. London,

Jessica Kingsley.

Laubeova Alvarez, I. \& Lorenzo M. 2003. Multicultural and intercultural education. Accessed from <URL> http://minorities.fsv.cuni.cz/multiculti/03/essays03/Alvarez.doc [Accessed on 27th June 2016].

Lingenfelter, S.G. \& Mayers, M.K. 2005. Ministering Cross-Culturally. Grand Rapids: Baker Academic.

Maiko, S. 2007. "The Youth in Africa" in Youth, Faith \& Culture. Bloomington: Author House, pp. 33-52.

McIntosh P. 1990. White Privilege: Unpacking the Invisible Backpack. Accessed from <URL> http://www.cirtl.net/files/PartI_CreatingAwareness_WhitePrivilegeUnpackingtheInvisibleKnapsack.pdf [Accessed on 14th June 2016].

McLaren, B.D. 2006. Church on the other Side. Grand Rapids: Zondervan.

Metanoia. 2017. Youth Leadership Pipeline. Accessed from <URL $>$ http://pushingforward. org/initiatives/building-leaders/youth-leadership-pipeline/ [Accessed on 07th August 2017].

Miller, R.C. 1997. "Bible, Theology, and Multicultural Religious Education" in Wilkerson, B. (ed.). Multicultural Religious Education. Birmingham: Religious Education Press, pp. 129-157

Moreleta Eastside Community Church, 2016. Who we are. Accessed from <URL > http:// moreleta.eastside.org.za/about-us/who-we-are/ [Accessed on 14th June 2016].

Naidoo, M. 2017. The potential of multicultural congregations in supporting social reconciliation. HTS Teologiese Studies/ Theological Studies, 73 (4), a4622. Available from https://doi.org/10.4102/hts.v73i4.4622

Naidoo, M. \& De Beer, S. 2016. Diversity: Negotiating difference in Christian communities. Accessed from <URL> http://www.hts.org.za/index.php/HTS/article/view/3525 [Accessed on 08th March 2017]. 
Niemand, R. 2012. Verbal communication with A. Strecker on 19 March. Pretoria, Parkview Shopping Centre. (Notes in possession of A. Strecker, Braidlandstr. 23, 4060 Leonding, Austria.)

Norris, A.E., Aroian, K.J., Warren, S. \& Wirth J. 2012. "Interactive performance and focus groups with adolescents: The power of play" in Research in Nursing and Health. 35, 6, 671-679.

Osmer, R.R. 2008. Practical Theology: An Introduction. Grand Rapids: Eerdmans Publishing. Parker, S. \& Girgis, R. (eds). 2005. Living the Vision. Becoming a Multicultural Church. Louisville: Congregational Ministries Publishing.

Parks, D. 1999. Multicultural youth ministry on the rise; 'safe and accepting place. Accessed from <URL> http://www.bpnews.net/412/multicultural-youth-ministry-on-therise-8216safe-and-accept ing-place [Accessed on 24th May 2016].

Parrett, G. 1999. "Ministering in the real world: A multicultural perspective on youth ministry" in Christian Education Journal. 3, 2, 38-45.

Pithers, R.T.2002. "Cognitive Learning Style: a review of the field dependent-field independent approach" in Journal of Vocational Education and Training, 54, 1, 117-132.

Ratcliff, D 1997. "Psychological Foundations of Multicultural Religious Education" in Wilkerson, B. (ed.) Multicultural Religious Education. BirminghamL Religious Education Press, pp. 93-128.

Rinquest, L. 2014. "The Quest for Identity in Baptist Churches in South Africa" in Conradie, E.M. \&

Klaasen, J. (eds). The Quest for Identity in so-called Mainline Churches in South Africa Stellenbosch: SUN Press Pp. 89-101.

Roebben, B. 2009. Youth, Culture and Theology in Plural. Louisville: IASYM. Savage, S. \& Collins-Mayo, S. 2011. Making sense of Generation Y: the world view of 15- to 25-year-olds. London: Church House Publishing.

Scheepers, A. 2012 What is the Baptist Union? Accessed from <URL> http://www.baptistunion.org.za/index.php/fi/faq/wbu [Accessed on 13th June 2016].

Schellebach, C. 2007. Developmental Stages. Blackwell Reference. Accessed from <URL $>$ $<$ http://0-www.sociologyencyclopedia.com.oasis.unisa.ac.za/subscriber/tocnode. html?id=g9781405124331_yr2016_chunk_g978140512433110_ss1-36> [Accessed on 22nd June 2017].

Senter, M.H., Black, W., Clark, C. \& Nel, M. 2001. Four views of youth ministry and the church: inclusive congregational, preparatory, missional, strategic. Grand Rapids: Zondervan.

Smith, K.G. 2010. "Review of Richard Osmer, Practical Theology: An Introduction" in Conspectus: The Journal of the South African Theological Seminary, 10, 99-113.

Sorber, J. 2010. "Multicultural Student Ministry" in Anderson D.A. \& Cabellon, M.R. (eds). Multicultural Ministry Connecting Creatively to a Diverse World. Downers Grove: IVP, pp. 131-145.

Sorber, J. 2016. Multicultural Youth Ministry Takes Intentionality. Accessed from <URL $>$ https://youthspecialties.com/blog/multicultural-youth-ministry-takes-intentionality/ [Accessed on 23rd January 2017]. 
Stake, R.E. 1995. "Analysis and Interpretation" in The Art of Case Study Research. Thousand Oaks: SAGE, pp. 71-90.

Steinberg, L. \& Morris, A.S. 2001. Adolescent Development. Accessed from <URL $>$ http://www.colorado.edu/ibs/jessor/psych7536-805/readings/steinberg_morris-2001_83-110.pdf [Accessed on 23rd June 2017].

Sue, D.W. 2011. The Challenge of Multiculturalism: The Road Less Travelled. Accessed from <URL > www.utm.edu/staff/aduncan/The\%2520Challenge $\% 2520$ of $\% 2520 \mathrm{Multicu}$ lturalism.pdf [Accessed on 5th August 2011].

Swinton, J. \& Mowat, H. 2006. Practical Theology and Qualitative Research. London: SCM.

Vandeyar, S. 2003. "The jagged paths to multicultural education: international experiences and South Africa's response in the new dispensation" in South African Journal of Education, 23, 193-198.

Wilkerson, B. (ed.) 1997. Multicultural Religious Education. Birmingham: Religious Education Press.

Yazan, B. 2015. The Qualitative Report 2015. Volume 20, Number 2, Teaching and Learning Article 1, 134-152. Availavble on http://www.nova.edu/ssss/QR/QR20/2/yazan1.pdf. 